\title{
Factors and Effect of Social Assistance Information to Donor Decision for NGO Crowdfunding in Indonesia
}

\author{
Husin Ali ${ }^{1}$, Roy Valiant Salomo ${ }^{2}$ \\ ${ }^{1,2}$ Faculty of Administrative Sciences, University of Indonesia, Depok, Indonesia \\ sinthehouse@gmail.com
}

\begin{abstract}
This research aims to find out the effect of social assistance information given by Non-Governmental Organizations (NGO) for donor decision to crowdfunding in Indonesia. Also find a relationship between the predicted factors (public trust, donor altruism, government participation) that related to the effectiveness of information that comes from the government and donor decision after social assistance information by NonGovernmental Organizations (NGO). The approach used in this research is a quantitative approach. The data used in this study are primary data, collected by using the interview method with a questionnaire. The sampling technique used is non-probability sampling with purposive sampling technique. The sample taken 200 respondents in various place in Indonesia. Data analysis techniques of this study are descriptive analysis techniques and Structural Equation Modeling (SEM) analysis techniques. The scale used in this study is a Likert scale. The results showed that social assistance information given by Non-Governmental Organizations (NGOs) has a positive effect on donor decision for crowdfunding in Indonesia.
\end{abstract}

Keywords

Non-Governmental

Organizations (NGO); social assistance information; donor decision; crowdfunding; public trust

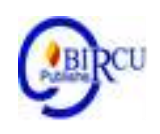

\section{Introduction}

Indonesia, the fourth most populated country globally, is an excellent example of poverty alleviation and improvement of the human development index (Ranis \& Stewart, 2012). One of the factors of concern is the Government's success in significant public expenditure policies in the social sector through transfer money to the people. The Indonesian Government announced that the poverty rate has been on a downward trend in the last 21 years (Biro Pusat Statistik, 2020). In 1998, the poverty rate reached $24.2 \%$ and continued to fall in 2019 to only one digit. It was recorded that the percentage of poor people in September 2019 was $9.22 \%$. In one year, this figure also decreased by $0.19 \%$ against March 2019 and 0.44\% against September 2018 (Figure 1). 


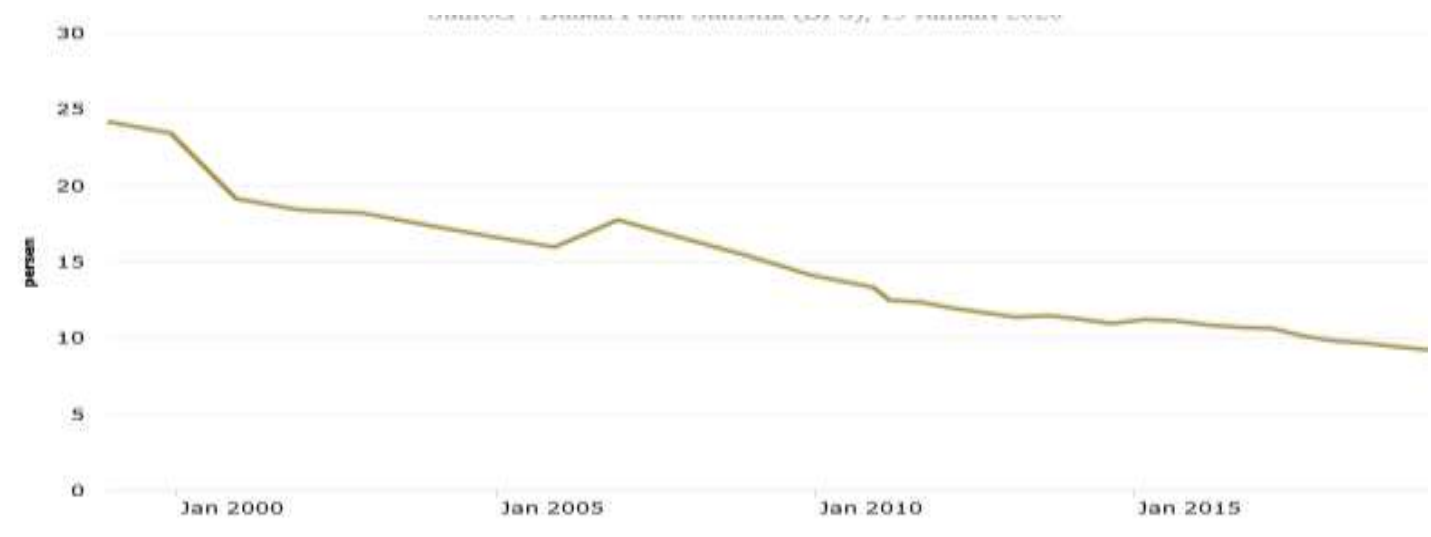

Figure 1. (Poverty rate trends 1998-2019)

Many poor people can prove that there has been an imbalance in social justice, which can cause social unrest and riots in society (Lanham, 2004). If multiplied by the total population, the percentage of poor people owned by Indonesia will produce a quantity that is not small. In line with this issue, the Indonesian Government continues to improve itself. This increase includes ensuring citizens' right to know about plans for making public policies, public policy programs, and public decision-making processes, as well as the reasons for making a public decision. The Government clearly stated this guarantee in the form of regulations, so that in 2008 they issued a law with the name Undang-Undang Republik Indonesia Nomor 14 Tahun 2008 tentang Keterbukaan Informasi Publik (UU KIP).

Therefore, the commitment of the Government of Indonesia in allocating assistance for underprivileged people is demonstrated through budget allocations based on the "Social Protection" function as regulated in "PMK No.114/PMK.02/2016" concerning Budget Classification. In this regulation, it is explained that the "Social Protection" account distributes funds for social protection in the form of money and goods. It is also regulated in Law number 17 of 2013 concerning Community Organizations (Ormas) which gives rights to mass organizations to obtain and manage grants and social assistance (BANSOS). The related technical rules are strengthened again in the Minister of Home Affairs Regulation Number 14 of 2016.

However, the Indonesian government has recently planned to reduce people's dependence on various forms of social assistance, especially ahead of the new Covid-19 normal period. The Coordinating Minister for Human Development and Culture, Muhadjir Effendy (2020) stated that, "We also see the tendency of dependence on social assistance, we must reduce this to a new normal. Then various kinds of activity fields, especially in the labor-intensive sector and other employment fields, have begun to open, because there has been a reduction in PSBB (Large-Scale Social Restrictions)".

Apart from structural deterioration, policies that have not been maximized (both in concept and implementation), another thing that is also a factor in poverty still haunts the nation is the low work ethic of the community. This work ethic belongs to what is often called cultural poverty. Unlike structural poverty, cultural poverty actually comes from within individuals and groups in society. Laziness, helplessness, lack of work ethic, and maintained habits cause them to be poor. Therefore, it is their own habits that cause them to not get out of poverty. (Dewi et al, 2018)

This paper seeks to find the effect of social assistance information given by NonGovernmental Organizations (NGOs) for donor decision to crowdfunding in Indonesia. Then, 
the predicted factors (public trust, donor altruism, government participation) that related to the effectiveness of information that comes from the government will be further reviewed to find a relationship between them and donor decision after social assistance information by Non-Governmental Organizations (NGOs).

\section{Research Methods}

The approach used in this research is a quantitative approach. In social science, a quantitative approach is used to measure behavior, opinions, or attitudes. This approach will answer questions related to how much, how often, how much, when, or who from one variable to another (Blumberg, Cooper, \& Schindler, 2014). The data used in this study are primary data collected using the interview method with a questionnaire. The sampling technique used is non-probability sampling with purposive sampling technique. The analytical method used is SEM (Structural Equation Modelling). The scale used in this study is a Likert scale which has a value from 1 to 6 . The analysis will also performed using descriptive statistics in the form of frequency and graphic output on the variables of domicile, gender, age, and occupation in order to obtain a complete picture of the demographic characteristics of the respondents

This research is planned to be conducted in second week of April in 2021. The research area is Indonesia, with data locking on research respondents. Research respondents were Indonesian citizens, with the distribution of questionnaires through the Whatsapp group media. The total population of Indonesia is 270.2 million people (Biro Pusat Statistik, 2020). From this data, using the joint probability method, the prediction of the number of Indonesians who donated using the crowdfunding method is 137.4 million people, with a spread of 77.5 million people in Java, 30.5 million people in Sumatra, 9.6 million people for Sulawesi, 8.6 million people for Kalimantan, 7.1 million people for Bali-Nusa, and 4.1 million people for Maluku-Papua Island. The sample taken in conducting this research will be 200 respondents, with details of the population of Java Island as many as 114 people, Sumatra by 46 people, Sulawesi by 14 people, Kalimantan by 12 people, Bali-Nusa by 10 people and Maluku-Papua Island by 4 people. Sampling is done by using a purposive sampling procedure, namely selecting samples based on considerations of several characteristics that are suitable with respect to sample members needed to answer the research objectives. The selected respondents are respondents who have made donations using the crowdfunding method.

\subsection{Data Analysis Technique}

a. Descriptive Analysis

Descriptive analysis techniques are used to describe the demographic data of respondents and research variable data. This descriptive analysis technique is to measure the amount of data (n), the central tendency, which in this study uses the arithmetic mean, and standard deviation (Ho, 2018). The standard deviation is the square of the difference between all data values and their calculated mean, or the root of the sample variance. (Kuncoro, 2011; Riana, 2012) The greater the standard deviation value means the higher the deviation of the data with the average value. If the standard deviation is $30 \%$ higher than the average value, then the standard deviation is classified as high (Kuncoro, 2011).

The average value of variable data is obtained by adding up the score values of these variables, then dividing the added value by the score (Ho, 2018). The technique of interpreting the mean value on a Likert scale of 1-6 uses the class interval formula (Riana, 2012). 


\section{b. Analysis of Structural Equation Modeling (SEM)}

The analysis technique at SEM-AMOS is in principle implemented in three stages as follows: (i) First, testing the measurement model. This measurement model is intended to obtain constructs, in this case the latent variables, which are fit. The latent variable that is fit allows the analysis to be continued at a later stage. Testing this measurement model uses Confirmatory Analysis Factor (CFA). (ii) Second, testing the structural model (structural measure). This test aims to obtain the most fit structural model, using the Goodness of Fit (GOF) test. (iii) Third, hypothesis testing (Haryono, 2017).

\subsection{Statistical Hypothesis}

In accordance with the hypothesis of this study, hypothesis testing (whether HO is rejected and $\mathrm{Ha}$ is accepted, or vice versa) with this linear regression analysis model consists of two partial effects. The size of the influence between variables and the positive or negative effects between these variables is based on the value of the structure coefficient that relates the latent variable to other latent variables, which can be seen in the SEM-AMOS output in the form of a standardized regression coefficient graph (Standardized Regression). Weights), or through the table "Standardized Regression Weights (Group number 1- Default model), in the Estimate column (Haryono, 2017; Widarjono, 2015)

Meanwhile, to assess the significance of each latent inter-variable influence through the use of SEM-AMOS is in two ways: (i) The first way, based on the p-value (p-value), by comparing the $\mathrm{p}$-value with the t-critical, or level significance, which in this study was 0.05 . If the p-value <critical value (0.05), then the influence between these variables is significant, and vice versa. (ii) The second way is to compare the critical value (CR) on regression weights (group number- Default model) and fit model. If the CR value is $\geq|1.96|$ or the probability value $(\mathrm{p}) \leq 0.05$, it means that the relationship between latent variables is significant. (Haryono, 2017; Widarjono, 2015).

\section{Results and Discussion}

\subsection{Analysis of Respondent Descriptions}

The survey, which was conducted through Google Forms for about 19 days, resulted in 213 respondents who returned the research questionnaire. After being selected by the criteria for completeness and quality of answers to the questions and statements in the questionnaire, 200 respondents were finally selected. Demographically, respondents were asked four general demographic characteristics, starting from gender, domicile, age, and occupation. A summary of the demographic data of respondents with $n=200$ is presented in Table 1 .

Table 1. Respondent Demographic Description

\begin{tabular}{|c|l|l|l|}
\hline No & \multicolumn{1}{|c|}{ Criteria } & Total Respondent (person) & Percentage \\
\hline 1. & Gender & & \\
\hline & Man & 136 & 68.0 \\
\hline & Woman & 64 & 32.0 \\
\hline & & 200 & 100.0 \\
\hline $\mathbf{2}$ & Domicile & & \\
\hline & Sumatera & 47 & 23.5 \\
\hline & Java & 113 & 56.5 \\
\hline & Kalimantan & 12 & 6.0 \\
\hline & Sulawesi & 14 & 7.0 \\
\hline & Bali-Nusa & 10 & 5.0 \\
\hline
\end{tabular}




\begin{tabular}{|l|l|l|l|}
\hline No & \multicolumn{1}{|c|}{ Criteria } & Total Respondent (person) & Percentage \\
\hline & Maluku & 4 & 2.0 \\
\hline & & 200 & 100.0 \\
\hline 3 & Age & 0 & \\
\hline & $<16$ & 6 & 0 \\
\hline & $16-25$ & 129 & 3.0 \\
\hline & $26-35$ & 41 & 64.5 \\
\hline & $36-45$ & 19 & 20.5 \\
\hline & $46-55$ & 5 & 9.5 \\
\hline & $>55$ & 200 & 2.5 \\
\hline & & & 100.0 \\
\hline $\mathbf{4}$ & Occupation & 1 & \\
\hline & Student & 33 & .5 \\
\hline & Private employees & 3 & 16.5 \\
\hline & BUMN / BUMD employees & 128 & 1.5 \\
\hline & ASN /PPPK/ PNS & 27 & 64.0 \\
\hline & Entrepreneur & 1 & 13.5 \\
\hline & Not yet working & 6 & .5 \\
\hline & Housewife & 1 & 3.0 \\
\hline & Retired & 200 & .5 \\
\hline & & 100.0 \\
\hline
\end{tabular}

Source: Processed from research results (2021)

Table 1. shows that most of the respondents (68 percent) were male. Then the rest (32 percent) are women. Judging from the domicile of the respondents, it appears that they are spread across six major islands in Indonesia. The largest number of respondents (56.5 percent) are domiciled in Java, followed by the second largest number of respondents (23.5 percent) who are domiciled in Sumatra. Respondents from the two islands comprise 80 percent of the respondents. As for 20 percent of respondents, including respondents who live in Sulawesi (7.0 percent), domiciled in Kalimantan (6.0 percent), domiciled in Bali-Nusa (5.0), and the smallest portion (2.0 percent) are respondents who live in Maluku Island.

\subsection{Validity test}

Test the validity of the construction of each questionnaire item in this study used factor analysis, namely by correlating the score of the instrument items in a factor, and correlating the factor score with the total score (Sugiyono, 2013). Statement items are considered valid if the validity value is greater than the product moment correlation value ( $\mathrm{r}$ table) at the 0.05 significance level. To find out " $r$ table", assuming the number of respondents is $30(n=30)$ and the degree of freedom or two-tailed Sig (hypothesis test results can be positive or negative) is 0.05 , then the value of "r table" is 0.365 .

Table 2. Validity Test Results for Donor Decision to Crowdfunding after Social Assistance Information Given by Non-Governmental Organizations (NGO) (DD)

\begin{tabular}{|c|c|c|c|c|c|}
\hline Indicator & $\begin{array}{c}\mathbf{r} \\
\text { Calculate }\end{array}$ & Description & Indicator & $\begin{array}{c}\mathbf{r} \\
\text { Calculate }\end{array}$ & Description \\
\hline Statement DD1 & 0.893 & Valid & Statement DD3 & 0.875 & Valid \\
\hline Statement DD2 & 0.904 & Valid & & & \\
\hline
\end{tabular}

Source: Processed from research results (2021) 
Table 3. Variable Validity Test Results of Public Trusts to NGO (PT)

\begin{tabular}{|c|c|c|l|c|c|}
\hline Indicator & r Calculate & Description & Indicator & $\begin{array}{c}\mathbf{r} \\
\text { Calculate }\end{array}$ & Description \\
\hline Statement PT1 & 0.884 & Valid & Statement PT3 & 0.833 & Valid \\
\hline Statement PT2 & 0.871 & Valid & Statement PT4 & 0.906 & Valid \\
\hline
\end{tabular}

Source: Processed from research results (2021)

Table 4. Results of Testing the Validity of Donor Altruism (DA) Variables

\begin{tabular}{|c|c|c|c|c|c|}
\hline Indicator & $\begin{array}{c}\mathbf{r} \\
\text { Calculate }\end{array}$ & Description & Indicator & $\begin{array}{c}\mathbf{r} \\
\text { Calculate }\end{array}$ & Description \\
\hline Statement DA1 & 0.844 & Valid & Statement DA3 & 0.831 & Valid \\
\hline Statement DA2 & 0.872 & Valid & & & \\
\hline
\end{tabular}

Source: Processed from research results (2021)

Table 5. Results of Testing the Validity of Government Presence (GP) Variables

\begin{tabular}{|c|c|c|c|c|c|}
\hline Indicator & $\begin{array}{c}\mathbf{r} \\
\text { Calculat } \\
\mathbf{e}\end{array}$ & $\begin{array}{c}\text { Descriptio } \\
\mathbf{n}\end{array}$ & Indicator & $\begin{array}{c}\mathbf{r} \\
\text { Calculat } \\
\mathbf{e}\end{array}$ & $\begin{array}{c}\text { Descriptio } \\
\mathbf{n}\end{array}$ \\
\hline Statement GP1 & 0.808 & Valid & Statement GP2 & 0.748 & Valid \\
\hline
\end{tabular}

Source: Processed from research results (2021)

\subsection{Reliability Test}

The second instrument test is the reliability test. A questionnaire is said to be reliable if the answers to the statements are consistent. If the reliability test results show that all items (all) of the questionnaire in the variable have an Alpha coefficient above 0.70, then the variable can be declared reliable. This means that these variables meet the minimum requirements for reliability, namely the Cronbach's Alpha coefficient> 0.70 (Ghozali, 2012).

Testing of variables (i) Donor Decision to Crowdfunding after Social Assistance Information Given by Non-Governmental Organizations (NGOs) (DD); (ii) Public Trusts to NGOs (PT); (iii) Donor Altruism (DA), and (iv) Government Presence (GP).

Table 6. Reliability Testing Results per Variable Method

\begin{tabular}{|l|l|l|l|}
\hline No & Variable & Cronbach's Alpha & Description \\
\hline 1. & $\begin{array}{l}\text { Donor Decision to Crowdfunding } \\
\text { after Social Assistance Information } \\
\text { Given by Non-Governmental } \\
\text { Organizations (NGOs) (DD) }\end{array}$ & 0.870 & Reliable \\
\hline 2. & Public Trust to NGOs (PT) & 0.805 & Reliable \\
\hline 3. & Donor Altruism (DA) & 0.805 & Reliable \\
\hline 4. & Government Presence (GP). & 0.884 & Reliable \\
\hline & & & \\
\hline
\end{tabular}

Source: Processed from research results (2021)

\subsection{Analysis of Variable Descriptions}

This study uses four variables, consisting of three independent variables and one dependent variable. How do respondents perceive each of these variables when implemented in the donor decision case study, the results are recapitulated in Table 7. 
Table 7. Description of Statement Items per Research Variable

\begin{tabular}{|c|c|c|c|c|}
\hline Variable & Item & Average & $\begin{array}{l}\text { Dimension } \\
\text { Average }\end{array}$ & $\begin{array}{c}\text { Total Average value } \\
\text { of the variables }\end{array}$ \\
\hline \multirow{4}{*}{ Public Trust } & PT1 & 4.97 & \multirow{4}{*}{4.96} & \multirow{12}{*}{16.80} \\
\hline & PT2 & 4.94 & & \\
\hline & PT3 & 4.83 & & \\
\hline & PT4 & 5.10 & & \\
\hline \multirow{3}{*}{ Donor Altruism } & DA1 & 5.01 & \multirow{3}{*}{4.83} & \\
\hline & DA2 & 4.85 & & \\
\hline & DA3 & 4.62 & & \\
\hline \multirow{2}{*}{$\begin{array}{l}\text { Government } \\
\text { Presence }\end{array}$} & GA1 & 2.00 & \multirow{2}{*}{2.12} & \\
\hline & GA2 & 2.24 & & \\
\hline \multirow{3}{*}{ Donor Decision } & DD1 & 4.88 & \multirow{3}{*}{4.88} & \\
\hline & DD2 & 4.86 & & \\
\hline & DD3 & 4.91 & & \\
\hline
\end{tabular}

Source: Processed from research results (2021)

The descriptive analysis of the research variables measures the central tendency, in this case is the arithmetic mean and standard deviation (Ho, 2018). The average value for the variable is calculated by adding the score of the variable and dividing the added value by the total score (Ho, 2018). In interpreting the average value on a Likert scale (1-6), a formula is used (Riana, 2012).

$$
\mathrm{I}=\mathrm{R} / \mathrm{K}
$$

where

$\mathrm{I}=$ Class Interval

$\mathrm{K}=$ Sum of class $=6($ Likert Scale $1-6)$

$\mathrm{R}=$ Max value - Min Value $=6-1=5$

Which mean that class intervals on the scale of this study is $\mathrm{I}=\mathrm{R} / \mathrm{K}=5 / 6=0,833$

In detail, the class intervals are as presented in Table 8.

Table 8. Class Intervals

\begin{tabular}{|l|l|}
\hline Class Interval in Likert 1-5 & Mean \\
\hline $1-1.833$ & Strongly Disagree \\
\hline $1.833<\mathrm{X} \leq 2.666$ & Disagree \\
\hline $2.666<\mathrm{X} \leq 3.499$ & Slightly Disagree \\
\hline $3.499<\mathrm{X} \leq 4.332$ & Slightly Agree \\
\hline $4.332<\mathrm{X} \leq 5.165$ & Agree \\
\hline $5.165<\mathrm{X} \leq 6.000$ & Strongly Agree \\
\hline
\end{tabular}

Class intervals for the Likert Scale 1-6 as presented in Table 8 can be a measure for the average value of the four research variables as presented in Table 7. 


\subsection{SEM-AMOS Analysis Results}

Analysis of structural equation modeling (SEM), in this case SEM-AMOS, is basically carried out in three stages, namely: (i) The first stage, testing the measurement model. This measurement model stage is intended to obtain a construct, in this case the latent variable, which is fit. A latent variable that is fit is a prerequisite so that SEM analysis can be continued at a later stage. The method of testing this measurement model uses Confirmatory Analysis Factor (CFA). (ii) The second stage, testing the structural model (structural measure). The purpose of structural model testing is to obtain the fittest structural model, using the Goodness of Fit (GOF) test. Model fit testing was carried out for the four variables of the study, namely three exogenous variables, namely Public Trust (PT), Donor Altruism (DA), Government Presence (GP), and one endogenous variable, namely Donor Decision (DA). (iii) The third stage is testing the research hypothesis (Haryono, 2017).

\subsection{Testing the Measurement Model}

The first stage of SEM-AMOS analysis is the model measurement test. This test is carried out using confirmatory factor analysis techniques or confirmatory factor analysis (CFA), which includes analysis of the CFA model and significance testing. This test aims to obtain the appropriate construct, so that the CFA model can be accepted. The CFA model can be accepted if it has a fit, and shows the model has sufficient reliability and validity (Haryono, 2017).

\subsection{Confirmatory Factor Analysis (CFA) Testing}

The purpose of the confirmatory factor analysis (CFA) test is to determine whether the model contains a negative variant and a critical ratio (CR) significance value that is less than |1.96| (Haryono, 2017). Negative variants occur, because of the Heywood case, which indicates the occurrence of an in-proper solution. The final model must not contain the Heywood case. The consequence is that if there is a negative variant, the negative variant must be eliminated in the final construct (Haryono, 2017). Testing the CFA model was carried out on the four research variable, namely Public Trust (PT), Donor Altruism (DA), Government Presence (GP), and one endogenous variable, namely Donor Decision (DD) using three research construct namely Public Trust (PT) to Donor Decision (DD), Donor Altruism (DA) to Donor Decision (DD), and Government Presence (GP) to Donor Decision (DD), as presented in Table 9., Table 10., and Table 11.

Table 9. Regression Weights: (Public Trust to Donor Decision - Default model)

\begin{tabular}{|c|c|c|c|c|c|c|c|}
\hline & & & Estimate & S.E. & C.R. & $\mathrm{P}$ & Label \\
\hline DonorDecision & $\begin{array}{l}<-- \\
\end{array}$ & PublicTrust & ,913 & ,072 & 12,655 & $* * *$ & par_5 \\
\hline DD1 & $<--$ & DonorDecision & 1,000 & & & & \\
\hline DD2 & $<---$ & DonorDecision & 1,048 & 077 & 13,582 & $* * *$ & par_4 \\
\hline DD3 & $<--$ & DonorDecision & 1,029 & ,077 & 13,350 & $* * *$ & par_6 \\
\hline PT1 & $<---$ & PublicTrust & 1,000 & & & & \\
\hline PT2 & $<--$ & PublicTrust & 887 & ,062 & 14,238 & *** & par_1 \\
\hline PT3 & $<--$ & PublicTrust & 913 & ,073 & 12,443 & $* * *$ & par_2 \\
\hline PT4 & $<--$ & PublicTrust & 969 & ,059 & 16,506 & $* * *$ & par_3 \\
\hline
\end{tabular}

Source: Processed from research results (2021) 
Table 10. Regression Weights: (Donor Altruism to Donor Decision - Default model)

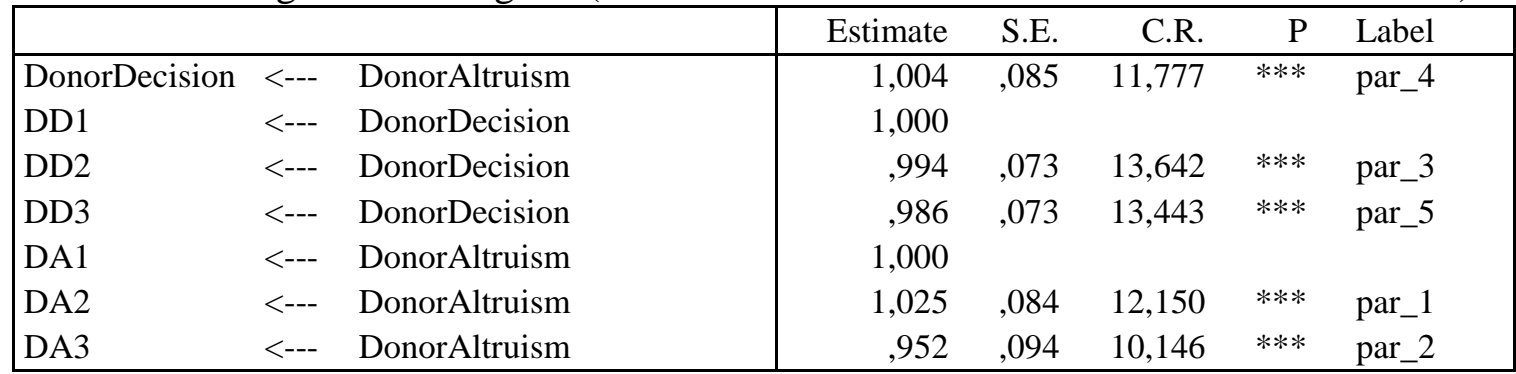

Source: Processed from research results (2021)

Table 11. Regression Weights: (Government Presence to Donor Decision - Default model)

\begin{tabular}{|c|c|c|c|c|c|c|c|}
\hline & & & Estimate & S.E. & C.R. & $\mathrm{P}$ & Label \\
\hline DonorDecision & $\begin{array}{l}<-- \\
\end{array}$ & GovernmentPresence &,- 347 & ,058 & $-5,980$ & **** & par_3 \\
\hline DD1 & $<--$ & DonorDecision & 1,000 & & & & \\
\hline DD2 & $<--$ & DonorDecision & 1,077 & 085 & 12,680 & $* * *$ & par_2 \\
\hline DD3 & $<--$ & DonorDecision & 899 & ,076 & 11,840 & $* * *$ & par_4 \\
\hline GP1 & & GovernmentPresence & 1,000 & & & & \\
\hline GP2 & $<--$ & GovernmentPresence & ,821 & ,092 & 8,913 & $* * *$ & par_1 \\
\hline
\end{tabular}

Source: Processed from research results (2021)

Table 9, Table 10, Table 11, show that of all the relationship indicators with latent constructs or variables, there is no negative variant. Likewise, the value between the indicator and the error term (S.E.) did not have a negative variant. This means that the model does not contain the Heywood case, which means that in this model there is no in-proper solution (Haryono, 2017). Thus, one of the CFA requirements is fulfilled, namely all variant is positive on the relationship between the indicator and the construct (latent variable) or the error term.

In addition, if looking at the significance value of the critical ratio (CR), as presented in Table 9, Table 10 and Table 11 for the three constructs, namely Public Trust (PT) to Donor Decision (DD), Donor Altruism (DA) to Donor Decision (DD), and Government Presence (GP) to Donor Decision (DD); then there is no CR value $<|1.96|$, meaning that there is no CR value less than 1.96. All CR values in the four constructs consisted of two digits on average, with a maximum value of 14.238 and a minimum of 5.980, which means that all of the constructs of this study had the CR value> 1.96. Thus, the three research constructs passed the CFA test.

\subsection{Significance Testing}

The test of significance is seen in the probability value ( $\mathrm{P}$ value), as shown in Table 9. Table 10, and Table 11. In the table, it can be seen that all latent variable relationships with other latent variables or between latent variables and their respective indicators ( $\mathrm{P}$ value) have a star $(* * *)$. Three star indicates a probability value $(\mathrm{P}$ value $)<0.05$, which means that all relationships between latent variables and latent variables and between latent variables and their respective indicator variables have a significant effect, regardless of whether the effect is positive or negative (Haryono, 2017). 


\subsection{Validity and Reliability Test}

\section{a. Validity Test}

The validity test in SEM-AMOS aims to determine the level of ability of an indicator (manifest variable) in measuring latent variables. A variable is said to have good validity against a latent construct if: (i) The $t$ value of the factor loading is greater than the critical $t$ value $\geq 1.96$ or practically $\geq 2$. This value is shown in the AMOS output. "Variances (Group Number) 1- Default model)". (ii) Standardized loading factors $\geq 0.5$.

Table 12. Validity Test with Factor Loading (Estimate) Public Trust to Donor Decision Constructs

\begin{tabular}{|ll|r|}
\hline & & Estimate \\
\hline DD1 <--- & DonorDecision &, 807 \\
DD2 <--- & DonorDecision &, 835 \\
DD3 <--- & DonorDecision &, 846 \\
PT1 <--- & PublicTrust &, 843 \\
PT2 $<---$ & PublicTrust &, 824 \\
PT3 $<---$ & PublicTrust &, 761 \\
PT4 <--- & PublicTrust &, 894 \\
\hline
\end{tabular}

Source: Processed from research results (2021)

Table 13. Validity Test with Factor Loading (Estimate) Donor Altruism to Donor Decision Constructs

\begin{tabular}{|ll|r|}
\hline & & Estimate \\
\hline DD1 <--- & DonorDecision &, 834 \\
DD2 <--- & DonorDecision &, 818 \\
DD3 <--- & DonorDecision &, 838 \\
DA1 <--- & DonorAltruism &, 799 \\
DA2 <--- & DonorAltruism &, 799 \\
DA3 <--- & DonorAltruism &, 698 \\
\hline
\end{tabular}

Source: Processed from research results (2021)

Table 14. Validity Test with Factor Loading (Estimate) Government Presence to Donor Decision Constructs

\begin{tabular}{|ll|r|}
\hline & & Estimate \\
\hline DD1 <--- & DonorDecision &, 835 \\
DD2 <--- & DonorDecision &, 887 \\
DD3 <--- & DonorDecision &, 764 \\
GA1 <--- & GovernmentPresence & 1,010 \\
GA2 <--- & GovernmentPresence &, 785 \\
\hline
\end{tabular}

Source: Processed from research results (2021)

Table 12. Table 13., and Table 14. shows that the value of the loading factor (Standardized Regression Weights) summarized from three construct, namely in the estimate column, are valid, because the loading factor value is greater than or equal to 0.05 (loading factor $\geq 0.05$ ). 


\section{b. Reliability Test}

Reliability test in SEM-AMOS aims to measure the level of consistency of the manifest variable in measuring its latent constructs. Hair et al., (2010) states that a construct has good reliability if: (i) the value of construct reliability (CR) is>1.96; and (ii) The average (average) variance extracted (VE) or AVE $\geq 0.5$.

As shown in Table 9., it appears that all the relationships between the first latent variable and the second latent variable, the value of the construct reliability $(\mathrm{CR})$ is greater than 1.96. This means that all indicator elements are proven to be reliable. In addition, the average (average) variance extracted (VE) or AVE $\geq 0.5$, as presented in Table 11.

Table 15. Reliability Test with AVE

\begin{tabular}{|lll|rr|}
\hline & & & Estimate & AVE \\
\hline DD1 & $<---$ & DonorDecision &, 807 & 0.829 \\
DD2 & $<---$ & DonorDecision &, 835 & \\
DD3 $<---$ & DonorDecision &, 846 & \\
$1<---$ & PublicTrust &, 843 & 0.831 \\
PT2 & $<---$ & PublicTrust &, 824 & \\
PT3 & $<---$ & PublicTrust &, 761 & \\
PT4 & $<---$ & PublicTrust &, 894 & \\
DA1 $<---$ & DonorAltruism &, 799 & 0,765 \\
DA2 $<---$ & DonorAltruism &, 799 & \\
DA3 $<---$ & DonorAltruism &, 698 & \\
GA1 $<---$ & GovernmentPresence & 1,010 & 0,897 \\
GA2 $<---$ & GovernmentPresence &, 785 & \\
\hline
\end{tabular}

Source: Processed from research results (2021)

Based on the reliability test results with the AVE value, as presented in Table 11., all constructs have an AVE value> 0.05, so that the construct is considered reliable. So, it can be concluded that it has met the reliability requirements.

\subsection{Social Assistance Information Given by Non-Governmental Organisations (NGOs) has a Positive Effect on Donor Decision for Crowdfunding in Indonesia}

Based on the descriptive analysis of the Donor Decision (DD) variable, the total average value has reached 4.88 on a Likert scale of 1-6 which means Agree, which means that Social assistance information given by Non-Governmental Organizations (NGOs) has a positive effect on donor decisions for crowdfunding in Indonesia. This means that the first hypothesis is proven.

The results of this study are in accordance with the results of previous studies. Research by Reyniers \& Bhalla's (2013), de Wit (2020) and Hughes et al. (2014) shows that other parties, including NGOs, can provide information that make donors have willing to make donations. However, the results of this study are not in line with the results of research by Horne et al. (2016) which found a negative influence on Social assistance information given by Non-Governmental Organizations (NGOs) on donor decisions. 


\subsection{Public Trust to NGOs has an Influence on Donor Decision after Social Assistance}

Information for Crowdfunding in Indonesia

Public Trust has a positive and significant effect on Donor Decision. This means that the research hypothesis 2 is proven. The results of this study support the research results of Taniguchi \& Marshall (2014) and de Vries et al (2015) which found that Public Trust has a positive and significant effect on Donor Decision.

Considering that public trust has a positive and significant effect on donor decisions, parties related to donor decisions must pay attention to public trust. Public trust is related to two parties, namely the public who gives trust, and another party who is given trust (trustee), in this case the crowdfunding institution. Trustees can be individuals, organizations, or systems. Public trust contains two things, namely the public giving authority to the trustee (crowdfunding institution); and at the same time the public is ready to accept the vulnerability of the trustee's behavior (crowdfunding institutions). The results show that public trusts are formed and maintained by trustees (crowdfunding institutions) with reference to past experiences, as well as beliefs or attitudes about competence, reliability, reputation, honesty, or the trustee's interests (crowfunding institution).

\section{Conclusion}

Based on the research results and related to the problem formulation and research hypotheses, it can be concluded that:

Based on the descriptive analysis of the Donor Decision (DD) variable with a total average value of 4.88 on a Likert scale of 1-6, which means Agree. Social assistance information given by Non-Governmental Organizations (NGOs) has a positive effect on donor decisions for crowdfunding in Indonesia, where donor agree to compensate more on donation if there were reduction in social assistance budget to NGOs. This means that the first hypothesis is proven. Public Trust to NGOs has a positive and significant effect on Donor Decision. Donor who have high trust to NGOs have a higher tendency to compensate more on donation if there were reduction in social assistance budget to NGOs. This means that the research hypothesis 2 is proven. Donor Altruism has a positive and significant effect on Donor Decision. Donor who have high level of altruism have a higher tendency to compensate more on donation if there were reduction in social assistance budget to NGOs. This means that the research hypothesis 3 is proven. Government Presence has a negative and significant effect on Donor Decision. Donor perception about government presence has shown a significant influence albeit shown a negative tendency to donor donation eventhough there were reduction in social assistance budget to NGOs. This means that the research hypothesis 4 is proven.

\section{References}

Adiansah, W., Mulyana, N., \& Fedryansyah, M. (2016). Potensi crowdfunding di indonesia dalam praktik pekerjaan sosial. Prosiding Penelitian dan Pengabdian kepada Masyarakat, 3(2). doi:10.24198/jppm.v3i2.13655

Andreoni, J. (1989). Giving with impure altruism: applications to charity and ricardian equivalence. Journal of Political Economy, 97(6), 1447-1458. Retrieved from http://remote-lib.ui.ac.id:2100/stable/1833247

Belleflamme, P., Lambert, T., \& Schwienbacher, A. (2014). Crowdfunding: Tapping the right crowd. Journal of Business Venturing, 29(5), 585-609. doi:10.1016/j.jbusvent.2013.07.003 
Blumberg, B., Cooper, D. R., \& Schindler, P. S. (2014). Business research methods (4. ed ed.). London: McGraw-Hill Education.

Charities Aid Foundation. (2019). CAF World Giving Index 10th edition. Retrieved from https://www.cafonline.org/

Cheema, G. S., \& Popovski, V. (2010). Building trust in government: innovations in governance reform in Asia (G. S. Cheema \& V. Popovski Eds.). Tokyo ; New York: United Nations University Press.

Cucciniello, M., Porumbescu, G. A., \& Grimmelikhuijsen, S. (2017). 25 Years of Transparency Research: Evidence and Future Directions. Public Administration Review, 77(1), 32-44. doi:10.1111/puar.12685

Darfian, A., Wildan, S., \& Gita Indah, M. (2018). Analisis Penerima Bantuan Sosial menggunakan Bayesian Belief Network. Jurnal RESTI (Rekayasa Sistem dan Teknologi Informasi), 2(2). doi:10.29207/resti.v2i2.447

Dewi, E. et al. (2018). Returning Government Policy for Poverty Reduction in Aceh. Budapest International Research and Critics Institute-Journal(BIRCI-Journal). P. 40-49

de Wit, A., \& Bekkers, R. (2020). Can Charitable Donations Compensate for a Reduction in Government Funding? The Role of Information. Public Administration Review, 80(2), 294-304. doi:10.1111/puar.13154

Dwiyanto, A. (2011). Mengembalikan kepercayaan publik melalui reformasi birokrasi. Jakarta: Gramedia Pustaka Utama.

existence noun - Definition, pictures, pronunciation and usage notes | Oxford Advanced Learner's Dictionary at OxfordLearnersDictionaries.com. Retrieved from https://www.oxfordlearnersdictionaries.com/definition/english/existence?q=existence

Ferreira Neto, A. B. (2018). Charity and public libraries: Does government funding crowd out donations? Journal of Cultural Economics, 42(4), 525-542. doi:10.1007/s10824018-9318-4

Gerber, E. M., \& Hui, J. (2013). Crowdfunding. ACM Transactions on Computer-Human Interaction, 20(6), 1-32. doi:10.1145/2530540

Gusinsky, M., Lyrio, M., Lunkes, R., \& Taliani, E. (2015). Accountability through citizen participation and transparency in the public sector: an analysis in the City Hall of Florianópolis / Brazil.

Hair, J. F. (2017). A primer on partial least squares structural equation modeling (Pls-sem) (J. F. Hair Ed. Second edition ed.). Los Angeles: Sage.

Heald, D. (2006). Varieties of transparency. In H. C (Ed.), Transparency: The Key to Better Governance? (pp. 25-43). New York: Oxford University Press.

Hommerová, D., \& Severová, L. (2018). Fundraising of Nonprofit Organizations: Specifics and New Possibilities. Journal of Social Service Research, 45(2), 181-192. doi:10.1080/01488376.2018.1479678

Horne, C. S., Johnson, J. L., \& Van Slyke, D. M. (2016). Do Charitable Donors Know Enough - and Care Enough-About Government Subsidies to Affect Private Giving to Nonprofit Organizations? Nonprofit and Voluntary Sector Quarterly, 34(1), 136-149. doi:10.1177/0899764004272192

Howe, J. (2006). The Rise of Crowdsourcing. Retrieved from https://www.wired.com/2006/06/crowds/

Hughes, P., Luksetich, W., \& Rooney, P. (2014). Crowding-Out and Fundraising Efforts. Nonprofit Management and Leadership, 24(4), 445-464. doi:10.1002/nml.21102

International Monetary Fund. (2014). Government finance statistics manual 2014 (F. International Monetary Ed.). Washington D.C: International Monetary Fund. 
Kim, S., \& Lee, J. (2012). E-Participation, Transparency, and Trust in Local Government. Public Administration Review, 72(6), 819-828. Retrieved from http://remotelib.ui.ac.id:2100/stable/41688008

Kitabisa. (2019). Kitabisa Online Giving Report 2018.

Kompas Cyber Media. (2019). Kemendagri Catat Jumlah Ormas Meningkat, Capai 431.465 Organisasi. Retrieved from https://nasional.kompas.com/read/2019/11/25/11151051/kemendagri-catat-jumlahormas-meningkat-capai-431465-organisasi?page=all

Kurniawan, T., \& Indriati, F. (2017). Introduction: Collaborative Governance in Dynamic Public-Private-Society Relations to Achieve Sustainable Development Goals. Development and society, 46(3), 421-426. doi:10.21588/dns/2017.46.3.001

Lanham. (2004, 2004 Dec 31). Good governance about issues of transparency, accountability, JAKARTA POST. WorldSources Online. Retrieved from https://search.proquest.com/docview/347508663? accountid=17242

Mardiasmo, -. (2011). Akuntansi sektor publik. Yogyakarta: Andi.

Mostert, E. (2003). The challenge of public participation. Water Policy, 5(2), 179-197. doi:10.2166/wp.2003.0011

Mourao, P., Silveira, M. A. P., \& de Melo, R. S. (2018). Many Are Never Too Many: An Analysis of Crowdfunding Projects in Brazil. International Journal of Financial Studies, 6(4). doi:10.3390/ijfs6040095

Norton, M. (2009). The worldwide fundraiser's handbook: a resource mobilisation guide for NGOs and community organisations (3 ed.). London: Directory of Social Change.

Peter, J. P., \& Olson, J. C. (2008). Consumer behavior and marketing strategy (8. ed., internat. ed ed.). Boston, Mass.: McGraw-Hill.

Prasetyawati, P. (2017). Tinjauan Hukum Crowdfunding Syariah Sebagai Media Alternatif Pembiayaan. University of Indonesia.

Rahayu, C. C. (2013). Penggalangan Dana Model Crowdfunding Di Indonesia.

Raho, B. (2007). Teori sosiologi modern.

Ranis, G., \& Stewart, F. (2012). Success and Failure in Human Development, 1970-2007. Journal of Human Development and Capabilities, 13(2), 167-195. doi:10.1080/19452829.2011.645026

Rasyid, M. A.-Z., Setyowati, R., fah, \& Islamiyati, I. (2017). Crowdfunding Syariah Untuk Pengembangan Produk Perbankan Syariah Dari Perspektif Shariah Compliance. Diponegoro Law Journal; Vol 6, No 4 (2017): Volume 6 Nomor 4, Tahun 2017. Retrieved from https://ejournal3.undip.ac.id/index.php/dlr/article/view/19778

Ribar, D., xa, C, Wilhelm, M., xa, \& O. (2002). Altruistic and Joy\&\#x2010; of\&\#x2010;Giving Motivations in Charitable Behavior. Journal of Political Economy, 110(2), 425-457. doi:10.1086/338750

Rutiana Dwi, W. (2011). Membangun Kepercayaan Publik melalui Kebijakan Sosial Inklusif. Jurnal Ilmu Sosial dan Ilmu Politik, 15(1), 29-40. doi:10.22146/jsp.10923

Salomo, R. V. (2011). Scenario Indonesia tahun 2025 dan tantangan yang dihadapi oleh administrasi publik. BISNIS \& BIROKRASI: Jurnal Ilmu Administrasi dan Organisasi, $16(2)$.

Sari, A. P. (2019). Pengaruh Brand Awareness, Kualitas Proyek Dan Kepercayaan Terhadap Keputusan Berdonasi Secara Online Pada Platform Crowdfunding Kitabisa. Com. Universitas Islam Negeri Sumatera Utara,

Schwienbacher, A., \& Larralde, B. (2010). Crowdfunding of Small Entrepreneurial Ventures. SSRN Electronic Journal. doi:10.2139/ssrn.1699183 
Shah, K. K., Sussex, J., \& Hernandez-Villafuerte, K. (2015). Government and charity funding of cancer research: public preferences and choices. Health Res Policy Syst, 13, 38. doi:10.1186/s12961-015-0027-6

Siagian, S. P. (2003). Administrasi pembangunan: konsep, dimensi, dan strateginya. Jakarta: Bumi Aksara.

Slothuus, R. (2007). Framing Deservingness to Win Support for Welfare State Retrenchment. Scandinavian Political Studies, 30(3), 323-344. doi:10.1111/j.1467-9477.2007.00183.x

Soekanto, S. (2002). Sosiologi: suatu pengantar. Jakarta: RajaGrafindo Persada.

Thaler, R. H. (1999). Mental accounting matters. Journal of Behavioral Decision Making, 12(3), 183.

Retrieved

from https://search.proquest.com/docview/214691604?accountid=17242

Tjiptono, F. (2018). Strategi pemasaran: Andi.

Tomczak, A., \& Brem, A. (2013). A conceptualized investment model of crowdfunding. Venture Capital, 15(4), 335-359. doi:10.1080/13691066.2013.847614

Tyasmara, N. C. (2016). Kebijakan Informasi Dan Pelaksanaan Undang-Undang No. 14 Tahun 2008 Tentang Keterbukaan Informasi Publik (KIP). University of Indonesia.

Wahjono, S., Marina, A., \& Fikry, M. (2015). Innovative funding solution for special projects: Crowd funding. Journal of Economics, Business, and Accountancy Ventura, 18, 65-74. doi:10.14414/jebav.15.1801006

Worthy, B. E. N. (2015). The Impact of Open Data in the Uk: Complex, Unpredictable, and Political. Public Administration, 93(3), 788-805. doi:10.1111/padm.12166 